\title{
Establish Renewable Resources for ASEAN Economic Community through Entrepreneurship Training as a Learning Model for Tutors of "Kejar Paket" C Programs
}

\author{
Tri Joko Raharjo ${ }^{1}$, Tri Suminar ${ }^{2}$, Bagus Kisworo ${ }^{3}$ \\ 1,2,3 Universitas Negeri Semarang, Indonesia \\ ${ }^{1}$ Coresponding email: trijokoraharjo@mail.unnes.ac.id
}

\begin{abstract}
Asean Economic Community (MEA) is a challenge for Non Formal Education in developing renewable human resources that are reliable, competitive, competent, professional and competitive with other countries. From this problem, it is necessary to develop Entrepreneurship training model for Tutors of Kejar Paket C as a change agent for the learning community as human resource which also need to be considered because they are competent to implement. The purpose of this research is to describe the model, implementation, and test of coca and evaluation of entrepreneurship training for the Tutors of Kejar Paket $\mathrm{C}$ to prepare learners as renewable human resources facing MEA. Methodology undertaken include preliminary study in the form of literature study, development stage and test phase. The hope of this entrepreneurship training model can be implemented and improve the competitiveness of human resources in facing the MEA. The results obtained from the analyzed instruments are obtained from the recruitment process, program implementation and field observation. From the calculation result for the percentage of recruitment according to the participant is good by giving the value in the average level range $80-90 \%$. At the time of implementation of entrepreneurship training also obtained good value in the range of $80-90 \%$. However, the participants still felt that the advice given by the resource persons for the field application was only $5 \%$ of the participants who felt that all the suggestions were easily implemented in the field.
\end{abstract}

Key words: Entrepreneurship Training, Learning Model for Tutors of "Kejar Paket" C Programs

\section{Introduction}

Asean Economic Community (AEC) known as the ASEAN Economic Community (MEA) has been launched. MEA is a form of cooperation between ASEAN members including Indonesia, Brunei Darussalam, Philippines, Singapore, Thailand, Cambodia, Laos, Myanmar and Vietnam. The cooperation enforces a trading system called "free trade". MEA has the impact of heavy competition in the world of work. The positive impact of the MEA is the opportunity for employers and job seekers to develop renewable human resources and more open access in the world market (Sholeh, 2013). While the negative impact that we can see from the MEA there is competition for imported goods entering Indonesia as well as outside human resources who are ready to work and have high potential.

Non formal education (PNF) must have a strategy in dealing with MEA. This is important because education is the basis for the creation of renewable, superior, innovative and characterized human resources. In this study focused on the trainning for tutor that will be represented by 20 tutor chase package $\mathrm{C}$ in Central Java. This study aims to get a tutor of Kejar Paket C programs as a nonformal school educator has a role in preparing citizens learn pa ket $\mathrm{C}$ to be a graduate who is ready, qualified and professional in the world of work in this era of MEA.

The learning process is done by enterpreneuship training for tutor of Kejar Paket C Programs which later can be applied in their place of teaching. Entrepreneurship training includes providing knowledge of skills and ability to self-employment, open employment and take advantage of business opportunities.

\section{Methods}

The study was carried out for 6 months from March - August 2018. The object of this study is 20 tutors passed on Kejar Paket C Programs derived from CLC 16 Packet C learning providers in cities / regencies in Central Java, among others, can be seen in Table 1.

In the early stages, researchers conducted a literature study, which was intended to collect the necessary data and in accordance with an effort to answer the purpose of the study (Sunarya, 2012). At this stage the researchers also conducted a study of the 
general description of community assets and daily activities of studying people in the group of Kejar Paket C Programs in some PKBM in Central Java as a potential base for pioneering the development of entrepreneurship trainning so as to obtain "data base line survey".

Table 1. Participants of entrepreneurship training models

\begin{tabular}{|c|c|c|}
\hline No & County town & Name of PKBM \\
\hline 1 & Banjarnegara & PKBM Insan Mandiri \\
\hline 2 & Banjarnegara & PKBM Pandawa \\
\hline 3 & Brebes & PKBM Mugi Sae \\
\hline 4 & Cilacap & PKBM Annisa \\
\hline 5 & Jepara & PKBM An Nur \\
\hline 6 & Karanganyar & PKBM Pionner \\
\hline 7 & Kendal & PKBM Kridatama \\
\hline 8 & Klaten & PKBM Harapan Bangsa \\
\hline 9 & Starch & PKBM Dewantara \\
\hline 10 & Pekalongan & $\begin{array}{l}\text { PKBM Arum } \\
\text { PKBM Ngudi Ilmu }\end{array}$ \\
\hline 11 & Pemalang & Barokah \\
\hline 12 & Purbalingga & PKBM Kartika \\
\hline 13 & Purworejo & PKBM Sawunggaling \\
\hline 14 & Rembang & PKBM Pusaka Ilmu \\
\hline 15 & Kab Semarang & PKBM Citra Ilmu \\
\hline 16 & Tegal & $\begin{array}{l}\text { Amanah PKBM } \\
\text { PKBM Cipta Karya }\end{array}$ \\
\hline 17 & Wonosobo & Mandiri \\
\hline 18 & Semarang city & PKBM Tunas Bangsa \\
\hline 19 & Semarang city & PKBM Pelita Mandiri \\
\hline 20 & Semarang city & PKBM Sendang Kawruh \\
\hline
\end{tabular}

At this stage the model development is based on the results of the literature study by: 1). Transfer the necessary knowledge, technology and skills by inviting competent sources through observation of the research object. Invite speakers in conducting research including academics and practitioners, among others. 2) Observation and interviews with research objects, identification of potentials, expertise controlled by studying citizens, analysis of potential economic activities, existing facilities through quisioners prepared by the researcher. 3) Validation of entrepreneurship training model development in the form of processing data by using colloquium method (Suryana, 2006). The test is conducted in the framework of feasibility test of the draft of entrepreneurship training model that has been done. Stages of the process are Preparation, Implementation, Socialization to the learning community, Monitoring and Reflection (Sujana, 2004)

\section{Results and Discussion Entrepreneurship training}

One of the learning programs at Community Learning Center (PKBM) is "Kejar Paket"C Programs for students equivalent to Upper School. Ministry of National Education through the Directorate of Non Formal Education expects PKBM can implement a learning system that can provide solutions to the community to improve the quality of human resources so that tutors play an important role to shape the readiness of learners in the face of globalization and MEA. In this research, entrepreneurship training activities for Package $\mathrm{C}$ trainers from PKBM scattered in Central Java are Semarang, Semarang, Grobogan, Rembang, Brebes. The existence of this entrepreneurship training to deliver vocational education that can provide additional knowledge, skills and abilities of students and improvement of attitudes and solutions to socio-economic problems of the students or PKBM itself. PKBM is indispensable as a place to encourage the creation of new jobs, while reducing unemployment, reducing social inequalities, preventing urbanization and fostering the economy of society. This entrepreneurship training is considered successful and this can be seen from the data instruments that have been distributed to participants, among others, recruitment instruments, entrepreneurial training implementation instruments and evaluation instruments. Recruitment is important because it is a means of realizing appropriate targeted entrepreneurship training in accordance with research objectives. Data on the success of recruitment of participants was obtained from the charging of quisioner by 20 tutor chase packet $C$ which can be seen in Table 2. 
Table 2. Recruitment Instruments of Entrepreneurship Training Participants

\begin{tabular}{cllcccc}
\hline \multirow{2}{*}{ No } & Training Program Implemented & \multicolumn{4}{c}{ Answer (\%) } & Total\% \\
\cline { 3 - 7 } & & $\begin{array}{c}\text { Very } \\
\text { clear }\end{array}$ & Clear & $\begin{array}{c}\text { Quite } \\
\text { clear }\end{array}$ & Unclear \\
\hline 1 & Training Objectives & 80 & 10 & 10 & 0 & 100 \\
2 & Selection of Training Participants & 10 & 80 & 10 & 0 & 100 \\
3 & Selection of Competent Participants & & & & & 100 \\
& for training & 90 & 10 & 0 & 0 & \\
4 & Letter of invitation to attend training & 90 & 10 & 0 & 0 & 100 \\
5 & Manual of training events & 10 & 90 & 0 & 0 & 100 \\
\hline
\end{tabular}

Table 3. Entrepreneurship Training Implementation Instrument

\begin{tabular}{|c|c|c|c|c|c|c|}
\hline \multirow[b]{2}{*}{ No } & \multirow{2}{*}{$\begin{array}{l}\text { Training Program } \\
\text { Implemented }\end{array}$} & \multicolumn{4}{|c|}{ Answer } & \multirow{2}{*}{$\begin{array}{l}\text { Total } \\
\% \\
\end{array}$} \\
\hline & & $\begin{array}{l}\text { Very } \\
\text { well }\end{array}$ & Good & $\begin{array}{l}\text { Pretty } \\
\text { good }\end{array}$ & $\begin{array}{l}\text { Not } \\
\text { good }\end{array}$ & \\
\hline 1 & Time allocation for all training & 0 & 80 & 10 & 10 & 100 \\
\hline 2 & $\begin{array}{l}\text { Time allocation for lectures and } \\
\text { question and answer }\end{array}$ & 0 & 10 & 90 & 0 & 100 \\
\hline 3 & $\begin{array}{l}\text { Allocation of time to practice } \\
\text { and simulation }\end{array}$ & 0 & 0 & 0 & 100 & 100 \\
\hline 4 & Material topics provided & 80 & 10 & 10 & 0 & 100 \\
\hline 5 & $\begin{array}{l}\text { Your understanding of the } \\
\text { training program }\end{array}$ & 10 & 80 & 10 & 0 & 100 \\
\hline 6 & $\begin{array}{l}\text { Available material / media } \\
\text { support equipment (laptop, lcd, } \\
\text { etc.) }\end{array}$ & 0 & 10 & 80 & 0 & 100 \\
\hline 7 & $\begin{array}{l}\text { Setting time for the material } \\
\text { provided }\end{array}$ & 0 & 5 & 80 & 15 & 100 \\
\hline 8 & $\begin{array}{l}\text { The ability of the resource } \\
\text { person to deliver the material }\end{array}$ & 5 & 90 & 5 & 0 & 100 \\
\hline 9 & $\begin{array}{l}\text { The ability of resource persons } \\
\text { to use methods to help present } \\
\text { material }\end{array}$ & 10 & 80 & 10 & 0 & 100 \\
\hline 10 & $\begin{array}{l}\text { The ability of the resource } \\
\text { person to use the media to help } \\
\text { present the material }\end{array}$ & 20 & 80 & 0 & 0 & 100 \\
\hline 11 & $\begin{array}{l}\text { The ability of resource persons } \\
\text { to direct the discussion }\end{array}$ & 10 & 90 & 0 & 0 & 100 \\
\hline 12 & $\begin{array}{l}\text { The ability of the resource } \\
\text { person to explain the training } \\
\text { materials }\end{array}$ & 10 & 85 & 5 & 0 & 100 \\
\hline 13 & $\begin{array}{l}\text { The ability of the resource } \\
\text { person to answer the questions } \\
\text { posed by the participants }\end{array}$ & 0 & 90 & 10 & 0 & 100 \\
\hline 14 & $\begin{array}{l}\text { The attitude of the training } \\
\text { committee towards participants }\end{array}$ & 10 & 90 & 0 & 0 & 100 \\
\hline 15 & $\begin{array}{l}\text { Tranquility and order of the } \\
\text { training room }\end{array}$ & 0 & 80 & 20 & 0 & 100 \\
\hline 16 & $\begin{array}{l}\text { The composition of the training } \\
\text { room }\end{array}$ & 0 & 0 & 80 & 20 & 100 \\
\hline 17 & Cleanliness of the training room & 0 & 90 & 10 & 0 & 100 \\
\hline
\end{tabular}


In table 2. it can be seen that the process of recruitment and dissemination of information on entrepreneurship training assessed by the participants is good.This can be seen from the percentage of values between $80-90 \%$ are in a very clear and clear position. Recruitment is carried out through the dissemination of information via email, via whatsapp and via letter to PKBM Forum Central Java.

The successful implementation of entrepreneurship training is an important indicator as well for the success of this research. An overview of the success of the learning model given during entrepreneurship training (Table 3). In table 3 it can be seen that the participant's assessment of the implementation of the average activity has a value of $80-90$ or better so that the learning method given can already be said good and complete.This is in accordance with the theory of Gagne and Brigss in Mukminan (2006) which states that:

"... The learning model is the equivalent of the instruction which means the process of making people learn. The goal is to help people learn or manipulate the environment to make it easier for people to learn. Model learning as a series of events that affect the learner so that the learning process can take place easily ".

As contained in Law No.20 of 2003 on National Education System Article 13 paragraph 1 which states that:

"Education can be implemented in formal, informal, and informal educational pathways that can be mutually enriching, organized with open systems face-to-face and / or remote".

From the article statement above illustrates that the entrepreneurship training process conducted in this study is in accordance with the learning method for nonformal education which is carried out in a structured manner by clarifying the specialization of the training participants, namely Kejar Paket C Programs Charter Tutors from PKBM throughout Central Java. his student.

\section{Field observation}

Field observation in this research was conducted at Kejar Paket C Citra Ilmu Regency of Semarang. Management of entrepreneurship in the image of science is based on local potential. The data of observation include the result of interview with the trainer of Kejar Paket $\mathrm{C}$ programs, the companion of entrepreneur / facilitator (nontechnical staff), employees, and stakeholders of PKBM Citra Ilmu. The analysis was also carried out on curriculum use, entrepreneurship learning methods provided, tutor activities, student activities, and business partners. Judging from the curriculum aspect, entrepreneurship learning material on PKBM Citra Ilmu is good and complete from business management theory to marketing, but if you consider from the time allocation for learning for entrepreneurship only 2 months this time is not enough to study entrepreneurship theory. There are many things to be learned such as business planning, business feasibility analysis, entrepreneurial attitude and personality, networking and managing cooperation with business partners.

Based on an interview with a Kejar paket $\mathrm{C}$ programming tutor entrepreneurship, that learning consists of theory and practice. The curriculum is structured by determining the learning objectives, determining the subject and determining the learning time. The curriculum adapts entrepreneurial vocational skills to be implemented. To measure the success of learners in receiving entrepreneurial materials, the organizers evaluate both theory and practice. Materials tested include: business management theory, group / team collaboration theory, technical skills theory related to entrepreneurship, theory about product marketing. The purpose of the material is taught so that learners have the ability to not only produce an item but also able to find capital, able to build partnerships, able to survive in the competition and able to market the product in the right way.

The results of interviews with students in Kejar Paket C PKBM Citra Ilmu obtained the description among others: the learners are expected to make business production equipment cultivated, have an understanding of the production process, have the ability to entrepreneurship, efforts to increase capital and seek relationships and partnerships with similar businesses. From the observation results obtained data that can be seen in Figure 1. 


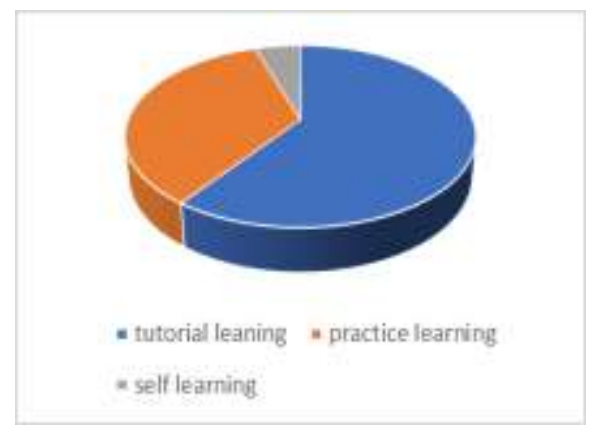

Figure 1. Percentage of Student Observation Results

In Figure 1. it can be seen that learners have a good understanding of the theory and practice of entrepreneurship. However, when they are asked to be independent to entrepreneurship process only $5 \%$ which has the level of self-employment independence, the rest still have with tutor guidance, facilitator and manager. This amount is directly proportional to the result in Figure 1.

From field observation recommended to the manager that approach and method of entrepreneurship learning appropriate for learners pursue Kejar Paket C Programs of PKBM Citra Ilmu is approach andragogy with learning method implemented in group. Characteristics of andragogy approach in entrepreneurship learning among others: students direct their own learning goals according to their potential, knowledge is a learning resource to direct further learning, students have learning awareness and desire because to meet their needs, students need a pilot model from the facilitator or tutor.

\section{Conclusion}

Entrepreneurship training has great potential to serve as a proper learning model in non-formal education in facing the current
MEA. Free competition in the world of globalization to pursue the role of chase tutors package $\mathrm{C}$ has the skills that support students to be able to become independent entrepreneurs.

\section{Refferences}

Mukminan, (2006) Desain Pembelajaran. FPIPS IKIP Yogyakarta

Sholeh. 2013. Preparation of Indonesia in Facing AEC (Asean Economic Community) 2015. eJournal of International Relations Science, 2013, 1 (2): 509-522.

Sujana, Djuju. 2004. Out of School Education, Insight, History of Development, Philosophy, Theory of Principle Development. Bandung: Falah Production.

Sunarya, Abas. 2012. Quantitative Research Methods Qualitataf and R \& D. Bandung: Alfabeta

Suryana, 2006. Entrepreneurship Practical Guidelines: Tips and Processes Towards Success, 3rd Edition, Jakarta: Salemba

Suroso, GT 2015. Asean Economic Community (MEA) and Indonesian Economy.http:

//www.bppk.kemenkeu.go.id/publikasi /artikel/150-artikel-keuangan-

umum/20545- economy- economic society- mea-and-economyindonesia. Retrieved on August 10, 2017 at $21.00 \mathrm{WIB}$.

Suttipun, Muttanachai. 2012. Readiness of accounting students in the ASEAN Economic Community: An empirical study from Thailand. Mae Fah Luang University: International Conference. 